\title{
PENGEMBANGAN PENGELOLAAN SAMPAH PERKOTAAN DENGAN POLA PEMANFAATAN SAMPAH BERBASIS MASYARAKAT
}

\author{
Slamet Raharjo, Taufiq Ihsan, Sri Rahmiwati Yuned \\ Jurusan Teknik Lingkungan, Fakultas Teknik, Universitas Andalas \\ Kampus Limau Manis, Padang, Telp. (0751)72497, Fax. (0751)72564 \\ *Email: sraharjo@ft.unand.ac.id
}

\begin{abstract}
ABSTRAK
Kota Bukittinggi dengan timbulan sampah 471,01 $\mathrm{m}^{3} /$ hari dan hanya terlayani 55,7\% dari total sampah. Permasalahan persampaan yang ada di Kota ini yaitu masih rendahnya praktek pemanfaatan sampah, selain itu adanya sampah kiriman dari kabupaten tetangga yang menyebabkan jumlah timbulan sampah meningkat, sementara Kota Bukittinggi tidak memiliki TPA sendiri. Untuk itu diperlukan perencanaan pengembangan pengelolaan sampah Kota Bukittinggi selama 20 tahun perencanaan (2016-2035) meliputi aspek teknis dengan pola pemanfaatan sampah. Pengelolaan persampahan yang direncanakan yaitu meningkatkan daerah pelayanan dengan dibagi menjadi 3 zona yaitu zona I, II dan III berdasarkan kawasan strategis kota dan tingkat pelayanan menjadi $100 \%$ pada zona prioritas (Zona I) dengan melakukan reduksi sampah melalui pengolahan di TPS $3 R$ berdasarkan target 3R, 20\% di akhir tahun perencanaan dengan sistem pengolahan berupa pengomposan dengan sistem takakura susun dan rotary kiln serta bank sampah untuk sampah kering yang bisa didaur ulang. Berdasarkan analisis perbandingan, adanya pengolahan sampah dapat mengurangi jumlah sarana prasarana pengelolaan sampah.
\end{abstract}

Kata kunci: Pengelolaan, Bukittinggi, Aspek Teknis dan Non Teknis, 3R

\section{ABSTRACT}

Bukittinggi generates around 471,01 $\mathrm{m}^{3} /$ day of municipal solid waste (MSW), in which only 55,7\% is managed by the local government. As many other cities, Bukttinggi is facing a problem of implementing recycling practice. Meanwhile, there are abundant of waste from coming from districts around the border area. Such problems result in a high generation of waste that must be transfered to landfill. In order to reduce the waste generation, Bukittinggi needs a 20 years-planning of MSW development which is based on recycling management (20162030). It includes technical aspect and non technical aspect. The purpose of this study is to increase service coverage by developing community-based recycling facilities (TPS 3R). Developing area is divided into 3 zones. The level of service in zone 1 is increased to $100 \%$ by practicing waste reduction management in TPS $3 R$.. $3 R$ target is set at $20 \%$ of total waste generation at the end of the planning year with management system such as takakura composting, rotary klin composting and dry garbage bank. Planning with community-based waste recycling will decrease the amount of waste management facilities.

Keywords: Waste Management, Bukittinggi, technical aspect, non technical aspect, $3 R$

\section{PENDAHULUAN}

\section{Latar Belakang}

Meningkatnya laju pembangunan, pertambahan penduduk, serta aktivitas dan tingkat sosial ekonomi masyarakat di Indonesia telah memicu terjadinya peningkatan jumlah timbulan sampah. Hal ini menjadi semakin berat dengan hanya dijalankannya paradigma lama pengelolaan sampah yang mengandalkan kegiatan pengumpulan, pengangkutan, dan pembuangan. Semua kegiatan tersebut membutuhkan anggaran yang semakin besar dari waktu ke waktu, bila tidak tersedia akan menimbulkan banyak masalah operasional seperti sampah yang tidak terangkut, fasilitas yang tidak memenuhi syarat, cara pengoperasian fasilitas yang tidak mengikuti ketentuan teknis, dan semakin 
habisnya lahan pembuangan.

Menurut Undang-undang No 18 Tahun 2008 Tentang Pengelolaan Sampah, Pengelolaan sampah rumah tangga dan sampah sejenis sampah rumah tangga terdiri atas pengurangan sampah dan penanganan sampah. Pengurangan sampah dapat dilakukan dengan metode 3R (Reuse, Reduce, dan Recycle) yang dapat dilakukan di sumber atau di Tempat Pengelolaan Sampah Terpadu (TPST) sementara untuk penanganan sampah dapat dilakukan dengan pemilahan sampah berdasarkan komponennya, pengumpulan, pemindahan dan pengangkutan sampah baik dari sumber ke tempat penampungan sementara (TPS) atau dari TPST menuju tempat pemprosesan akhir.

Kota Bukittinggi tidak luput dari permasalahan persampahan. Sebagai kota pariwisata, banyaknya pangunjung di kota ini terutama di hari libur, peningkatan jumlah penduduk kota menyebabkan produksi sampah juga ikut meningkat, sementara daerah dan tingkat pelayanan sampah Kota ini belum merata yang menyebabkan pengelolaan sampah yang ada di Kota Bukittinggi ini tidak tertata dengan baik pada kondisi tertentu. Rendahnya praktek pemanfaatan sampah (3R) juga menjadi permasalahan dalam pengelolaan persampahan Kota. Selain permasalahan tersebut, adanya sampah kiriman dari kabupaten Agam yang berasal dari masyarakatnya yang bekerja di Kota Bukittinggi juga menyebabkan jumlah timbulan sampah Kota Bukittinggi meningkat. Untuk itu pada perencanaan ini diharapkan dapat direncanakan kegiatan pengembangan yang sesuai dengan kondisi eksistng wilayah perencanaan.

\section{Maksud}

Maksud dari perencanaan ini adalah merencanakan pengembangan pengelolaan sampah perkotaan di Kota Bukittinggi dengan pola pemanfaatan sampah berbasis masyarakat.

\section{Tujuan}

Tujuan dari perencanaan ini adalah:

1. Mengevaluasi sistem pengelolaan persampahan di Kota Bukittinggi;

2. Merencanakan daerah dan tingkat pelayanan serta target 3R di Kota Bukittinggi;
3. Merencanakan aspek teknis dan dengan pola pemanfaatan sampah;

4. Menganalisis perbandingan sistem Konvesional dan sistem 3R.

\section{METODOLOGI}

Lokasi Perencanaan terletak di Kota Bukittinggi dengan luas 2,239 $\mathrm{km}^{2}$. Dengan jumlah penduduk tahun 2014 sebanyak 120.491 jiwa. Dengan tahapan perencanaan sebagai berikut:

1. Studi Literatur

Studi literatur bertujuan untuk mengumpulkan dan mempelajari teori yang mendukung dalam rancangan pengembangan sistem pengelolaan sampah Kota Bukittinggi yang bersumber dari buku teks, jurnal dan penelitian sebelumnya.

2. Pengumpulan Data

Pengumpulan data merupakan langkah penting dalam proses penyusunan studi dan pengembangan sistem pengelolaan persampahan, karena tingkat kearutan data menjadi kunci dalam memproyeksikan rencana pengembangan selama jangka waktu perencanaan. Adapun jenis data yang dikumpulkan berupa data Primer (yang diperoleh dari kuisioner dan suvei lapangan) dan data sekunder (yang diperoleh Telaah dokumen terkait sistem pengelolaan persampahan Kota Bukittinggi.

3. Identifikasi Permasalahan

Identifikasi permasalahan dan kebutuhan pengembangan aspek teknis dan non teknis pengelolaan sampah Kota Bukittinggi

4. Perencanaan

Perencanaan akan dilakukan jangka waktu 20 Tahun, dengan 3 tahap perencanaan:

a. Tahap I (2016-2020), jangka pendek;

b. Tahap II (2021-2025), jangka menengah;

c. Tahap III (2026-2035), jangka panjang.

Dengan merencanakan aspek teknis berbasis masyarakat dengan prinsip 3R.

KONDISI EKSISTING PENGELOLAAN PERSAMPAHAN KOTA BUKITTINGGI

\section{Umum}

Satuan timbulan sampah domestik Kota Bukittinggi sebesar 2,9 1/o/h. atau $0,22 \mathrm{~kg} / \mathrm{o} / \mathrm{h}$. Dengan persentase sampah non domestik terhadap sampah domestik sebesar 32,6\%, 
yaitu sebanyak 114,01 $\mathrm{m}^{3} / \mathrm{h}$ sampah non domestik yang dihasilkan terhadap total sampah Kota Bukittinggi pada hari biasa (Tabel 1). Rasio sampah domestik hari biasa dan lebaran yaitu, 1: 1,06, sementara untuk sampah non domestik, yaitu 1: 1,02 (DKP Kota Bukittinggi, 2015). Dengan total timbulan hari iasa dan lebaran dapat dilihat pada Tabel 1.

Sistem pengelolaan sampah Kota Bukittinggi umumnya masih menerapakan sistem kumpulangkut-buang. Skema pengelolaan sampah Kota Bukittinggi dapat dilihat pada Gambar 1. Berdasarkan skema di atas pengelolaan sampah di Kota Bukittinggi diawali dengan pewadahan sampah di sumber tanpa pemilahan, kemudian sampah di sumber diangkut dengan pola pengangkutan individual tidak langsung menggunakan gerobak sampah, becak sampah dan becak motor, komunal tidak langsung dan penyapuan jalan. Selanjutnya dikumpulkan di TPS diangkut dengan menggunakan dump truck $\begin{array}{llllll}\text { kapasitas } & 8 & \mathrm{~m}^{3} & \text { menuju TPA Regional }\end{array}$ Payakumbuh dengan sistem Sanitary Landfill. Pengelolaan sampah Kota Bukittinggi merupakan pengelolaan skala Kota yang dilakukan oleh DKP Kota Bukittinggi.

Tabel 1. Timbulan Sampah Kota Bukittinggi Hari Biasa dan Lebaran

\begin{tabular}{lcc}
\hline \multicolumn{1}{c}{$\begin{array}{c}\text { Sumber } \\
\text { Sampah }\end{array}$} & Hotal Timbulan (mªsa & $\begin{array}{c}\text { Hari } \\
\text { Lebaran }\end{array}$ \\
\cline { 2 - 3 } Domestik & 349,42 & 368,70 \\
\hline $\begin{array}{l}\text { Perkantoran dan } \\
\text { fasilitas umum }\end{array}$ & 0,30 & 0,30 \\
\hline Sekolah & 0,35 & - \\
\hline $\begin{array}{l}\text { Hotel \& } \\
\text { Penginapan }\end{array}$ & 0,57 & 0,57 \\
\hline $\begin{array}{l}\text { Restoran \& } \\
\text { Rumah Makan }\end{array}$ & 4,75 & 4,753 \\
\hline Jalan & 3,17 & 13,74 \\
\hline Rumah sakit & 17,59 & 16,61 \\
\hline Pasar & 13,07 & 77,15 \\
\hline Toko \& Industri & 74,21 & $\mathbf{4 6 9 , 2 0}$ \\
\hline Total Timbulan & $\mathbf{4 6 3 , 4 3}$ & \\
\hline $\begin{array}{l}\text { Sumber: Dinas } \\
\text { Bukittinggi, 2014 }\end{array}$ & &
\end{tabular}

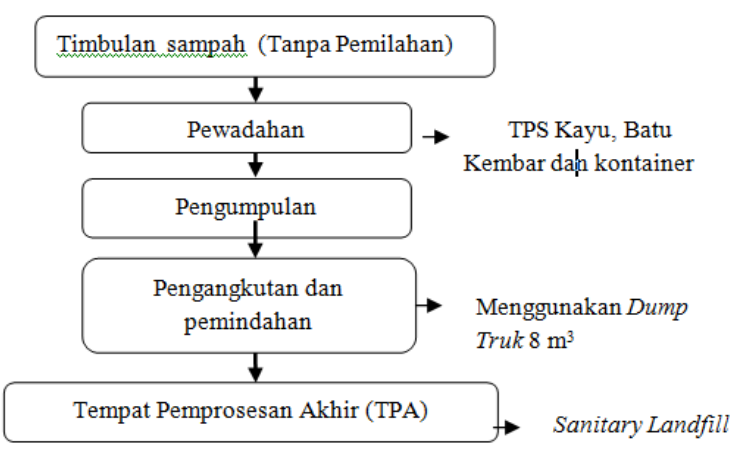

Gambar 1. Skema Pengelolaan Sampah Kota Bukittinggi Eksisting

\section{Pengolahan Sampah}

Pemerintah Kota Bukittinggi hingga 2014 belum melaksanakan pengelolaan sampah $3 \mathrm{R}$ dengan baik Fasilitas kota terkait $3 R$ yang sudah ada yaitu gedung fisik TPS 3R (Tempat Pengolahan Sampah) berbasis 3R yang berlokasi di Aur Kuning, namun pada realisasinya gedung ini belum digunakan sama sekali yang disebabkan oleh beberapa faktor. Kegiatan persampahan 3R di Kota Bukittinggi yang ada adalah pengolahan persampahan berbasis masyarakat. Kegiatan ini pembuatan kerajinan dari bahan daur ulang dan pengomposan. Kegiatan kerajinan daur ulang dan pengomposan yang ada di Kota Bukittinggi ini tidak memiliki lokasi pasti kegiatan 3R ini merupakan kegiatan pembinaan kesejahteraan Keluarga (PKK) yang hanya dilakukan ketika PKK memiliki program untuk melakukan pembinaan daur ulang kepada masyarakatnya. Berdasarkan hal tersebut menyebakna tidak terdatanya potensi 3R Kota Bukittinggi.

\section{Analisis Permasalahan}

1. Timbulan Sampah

a. Adanya sampah kiriman dari luar yang menambah timbulan sampah

b. Masih adanya masyarakat yang masih melakukan penimbunan dan pembakaran sampah.

2. Tingkat dan daerah pelayanan

Daerah pelayanan sampah sebesar 65,3\% dan tingkat pelayanan sampah tahun 2015 adalah sebesar 55,7 \% hal ini masih berada cukup jauh dari target RPJMN 2014, yaitu $100 \%$. Rincian tingkat pelayanan per kecamatan dapat dilihat pada Tabel 2. 


\section{Tabel 2. Tingkat Pelayanan Per Kecamatan Berdasarakan daya Tampung Sampah Tahun 2015}

\begin{tabular}{|lcrr|}
\hline $\begin{array}{c}\text { Kecamata } \\
\mathbf{n}\end{array}$ & $\begin{array}{c}\text { Timbulan } \\
\text { Sampah } \\
\left(\mathbf{m}^{\mathbf{3} / \mathbf{h})}\right.\end{array}$ & $\begin{array}{c}\text { Daya } \\
\text { Tampun } \\
\mathbf{g} \\
\text { Sampah } \\
\left(\mathbf{m}^{\mathbf{3}} \mathbf{h}\right)\end{array}$ & $\begin{array}{c}\text { Tingkat } \\
\text { Pelayan } \\
\text { an }(\mathbf{\%})\end{array}$ \\
\hline $\begin{array}{l}\text { Guguk } \\
\text { Panjang }\end{array}$ & 172,83 & 143,96 & 83,30 \\
\hline $\begin{array}{l}\text { Aur Birugo } \\
\text { Tigo Baleh }\end{array}$ & 104,73 & 62,84 & 60,0 \\
\hline $\begin{array}{l}\text { Mandingin } \\
\begin{array}{l}\text { Koto } \\
\text { Selayan }\end{array}\end{array}$ & & & \\
\hline & 193,45 & 65 & 33,6 \\
\hline
\end{tabular}

3. Aspek Teknis

a. Pewadahan

Sistem pewadahan individual Kota Bukittinggi berasal dari pihak masyarakat itu sendiri hal ini dapat dilihat dari hasil kuesioner, dengan wadah berupa karung/keranjang, plastik dan ember. Sistem pewadahan Komunal yang ada di Kota Bukittinggi ini masih memakai pewadahan sistem tercampur untuk TPS batu, kayu dan kontainer, namun untuk TPS kembar. jumlah wadah yang sudah disediakan oleh pemerintah Kota Bukitinggi tidak mencukupi dengan jumlah sampah yang dihasilkan, dengan daya tampung pewadahan yang sudah ada sebesar 271,8 $\mathrm{m}^{3} / \mathrm{h}$ sementara total volume sampah yang dihasilkan Kota Bukittinggi sebesar 471,01 $\mathrm{m}^{3} / \mathrm{h}$.

b. Pengumpulan

Pola pengumpulan yang di Kota Bukittinggi ini yaitu pola komunal tidak langsung, pola individual tidak langsung da pola penyapuan jalan. Dengan sistem pengumpulan sampah tanpa pemilahan sama sekali. Permasalahan untuk sistem pengangkutan yang ada pada pola pengumpulan komunal tidak langsung, masyarakat membuang sampah secara sembarangan tanpa memperhatikan sampah yang dibuang masuk ke dalam TPS atau tidak. Jumlah sarana dan prasarana untuk pengumpulan sampah di Kota Bukittinggi tidak mencukupi dengan total jumlah sampah yang ada di Kota Bukittinggi sebesar 466,95 $\mathrm{m}^{3} /$ hari dengan kapasitas tampung sarana-prasarana yang sudah ada sebesar $269 \mathrm{~m}^{3} / \mathrm{hari}$.

c. Pengangkutan sistem pengangkutan Kota Bukittinggi ini terkendala pada jumlag sarana prasarana, dimana jumlah truk yang ada untuk mengangkut jumlah total sampah belum mencukupi. jumlah dump truk sampah 16 dengan dua ritasi hanya bisa mengangkut sampah sebesar $192 \mathrm{~m}^{3} / \mathrm{hari}$ sementara sampah yang harus diangkut secara keseluruahan sebasar $471,01 \mathrm{~m}^{3} /$ hari.

d. Sistem Pengolahan Sampah

Berdasarkan data yang diperoleh ada beberapa kelurahan, yaitu kelurahan Campago Guguk Bulek, Pulai Anak Aia, Belakang Balok, Aur Kuning dan Bukit Cangang. yang menerapkan sistem pengelolaan $3 \mathrm{R}$ yang berbasis masyarakat berupa kegiatan pengomposan, kerajian daur ulang. Namun tidak terdata persentase kegiatan 3R yang diolah, karena kegiatan tidak menetap dan tidak berkelanjutan. TPS 3R di Aur Kuning memang telah mempunyai sarana fisik yang memiliki area pengomposan dan area penyimpanan sampah kering yang di arahkan sebagai pengolahan pengomposan dan daur ulang, namun belum beroperasi.

e. Tempat Pemrosesan Akhir (TPA)

Permasalahan TPA untuk Kota Bukittinggi ini adalah TPA Panorama Bukittinggi dengan sistem open dumping tidak sesuai dengan UU No 18 Tahun 2008. Hal ini menyebabkan Kota Bukittinggi tidak mempunyai TPA sendiri, Jarak antara Kota Bukittinggi ke TPA Regional > $25 \mathrm{~km}$. sehingga terlalu banyak jam kerja pada proses pengangkutan.

\section{Analisis Kebutuhan Pengembangan}

Berdasarkan Permasalahan-permasalahan yang ada, kebutuhan pengembangan yang perlu ada diantaranya:

1. Perlu adanya sosialisasi pemilahan sampah di sumber;

2. Menekan jumlah timbulan sampah kiriman;

3. Peningkatan daerah pelayanan hingga mencapai standar pelayanan minimal pada jangka pndek dan zona prioritas dan terus terjadi peningkatan pada periode desain jangka panjang;

4. Perlunya adanya zonasi guna mempermudah monitoring dan pengembangan pengolahan $3 \mathrm{R}$ dengan peningkatan daerah pelayanan di zona prioritas mencapai $100 \%$; 
5. Penambahan sarana prasarana pewadahan komunal, pengumpulan, pengangkutan, dan pengolahan sampah dengan target $3 \mathrm{R}$ sebesar 20\%(Permen Pu, no. 03 Tahun 2013) serta diharapkan bangunan pengolahan sampah yang sudah ada dapat beroperasi pada tahun pertama jangka pendek;

6. Melakukan penutupan TPA Panorama dan menghitung kebutuhan luas TPA;

7. Penambahan bidang pengolahan sampah (3R berbasis masyarakat), mengoptimalkan tetribusi masyarakat, penegasan terhadap peraturan, serta peningkatan peran serta masyarakat melalui sosialisasi dan pelatihan terkait pengelolaan sampah paradigma baru (adanya sistem pengolahan sampah).

\section{SKENARIO PENGEMBANGAN}

\section{Dasar Pengembangan}

a. Rencana Tata Ruang Wilayah (RTRW)

Perencanaan umum pengembangan pengelolaan sampah Kota Bukittingi mengikuti lamanya perencanaan RTRW Kota Bukittinggi dengan penetapan pembagian Zona mengacu pada kawasan strategis yang terdapat pada RTRW.

a. RPJMN 2014

Target tingkat pelayanan sampah mencapai 100 $\%$ pada zona prioritas di akhir periode jangka pendek perencanaan, sesuai dengan target RPJMN tahun 2014, dimana tingkat pelayan sanitasi yang salah satunya mengenai pengolahan sampah mencapai $100 \%$ pada tahun 2019.

b. Hasil Kuisioner

Berdasarkan hasil kuesioner dari 20 responden di Kelurahan yang memiliki bangunan fisik pengolahan sampah (Kelurahan Aur Kuning). Berdasarkan hasil kuesioner yang ada prilaku masyarakat dalam pengelolaan sampah dapat dilihat pada Tabel 3.

Berdasarkan Tabel 3 diatas dapat dilihat, masyarakat Kota Bukittinggi yang masih melakukan penimbunan dan pembakaran sampah, lalu belum adanya kepedulian masyarakat untuk memanfaatkan sampah yang masih bisa digunakan, karena hanya 5\% yang melakukan pengolahan sampah disumber. Terkait prencanaan pengolahan sampah dengan sistem 3R, berdasarkan hasil kuesioner keinginan masyarakat terhadap adanya pengolahan sampah yang akan dikembangkan dapat dilihat pada Gambar 2.

Tabel 3. Hasil Kuesioner terkait Perlakuan Sampah oleh Masyarakat Kota Bukittinggi

\begin{tabular}{|clr|}
\hline No & \multicolumn{1}{c}{ Jenis Perlakuan } & Persentase (\%) \\
\hline 1 & Dibuang ke sungai & 0,00 \\
\hline 2 & Dibakar & 20 \\
\hline 3 & Ditimbun Ditanah & 10 \\
\hline 4 & Dikumpulkan petugas & 65 \\
\hline 5 & $\begin{array}{l}\text { Diolah (Kompos dan } \\
\text { daur ulang) }\end{array}$ \\
\hline
\end{tabular}

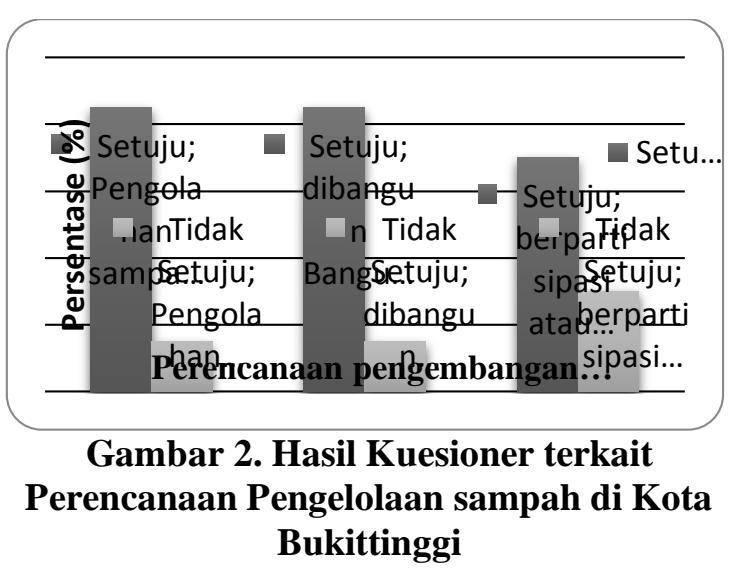

Berdasarkan Gambar 2, dapat dilihat adanya keinginan atau partisipasi masyarakat terhadap perencanaan pengolahan sampah yang dilakukan, sebanyak $85 \%$ masyarakat setujua adanya pengolahan sampah berbasis $3 \mathrm{R}$ dan dibangun bangunan fisik pengolahan sampah, namun hanya $70 \%$ masyarakat yang mau berpartisipasi langsung dalam pengolahan sampah.

c. Hasil Wawancara

Bedasarkan hasil wawancara perencana dengan Dinas Kebersihan dan Partmanan (DKP) Kota Bukittinggi, perencanaan pengembangan pengelolaan sampah yang diinginkan selama 20 tahun, dengan sistem pengelolaan sampah menerapkan pengolahan sampah di Tempat Pengolahan Sampah dengan metode 3R(TPS 3R). pengolahan sampah yang ingin direncanakan berupa pengomposan dan daur ulang sampah.

d. Pembagian Zona-Zona Pengembangan 
Dasar pembagian zona-zona pengembangan dalam pengembangan pengelolaan sampah Kota Bukittinggi adalah sebagai berikut:

1) Daerah dan tingkat pelayanan eksisting Zona prioritas dipilih, berdasarkan tingkat dan daerah pelayanan yang paling tinggi. Dan untuk zona selanjutnya dengan tingkat dan daerah pelayanan yang ada dibawah zona prioritas.

2) Kawasan strategis

Pembagian zona berdasarkan kawasan strategis ini, merujuk pada banyak nya kawasan strategis pada pembagian yang direncanakan, dimana jumlah kwasan stretgis terbanyak dijadikan sebagia zona prioritas.

3) Kepadatan penduduk

Kawasan dengan kepadatan penduduk teringgi dijadikan sebagia zona prioritas, dengan kepadatan penduduk terpadat menjadi zona prioritas.

Pembagian zona direncanakan menjadi 3 Zona, agar monitoring pengelolaan persampahan tidak terlalu luas. Berdasarkan pertimbangan yang telah disebutkan diatas, Zona Prioritas (Zona I) adalah Kecamatan Guguk Panjang, Zona II Kecamatan Aur Birugo Tigo Baleh dan Zona III Kecamatan Mandiangin Koto Selayan, dimana Zona II dan III merupakan Zona yag akan terus dikembangkan dalam pengelolaan sampah. Pembagian zona pengembangan dapat dilihat pada Gambar 3.

e. Kenaikan Tingkat dan Daerah Pelayanan selama periode tahun perencanaan

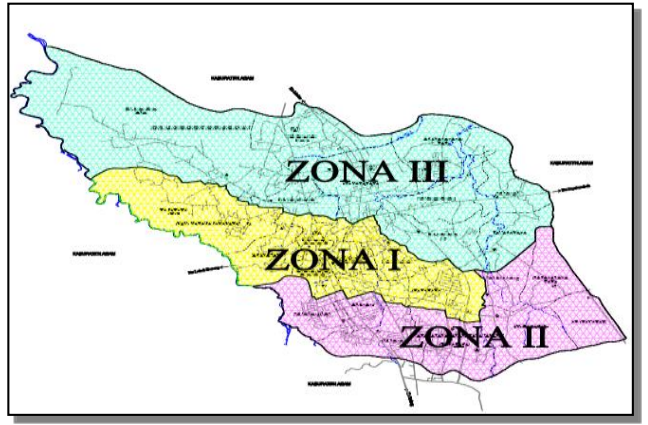

Gambar 3. Peta Pembagian Zona Pengembangan Kota Bukittinggi

Berdasarakan zona-zona pengembangan yang ada, direncanakan daerah dan tingkat pelayanan, serta target 3R meningkat setiap tahunnya dengan kenaikan tingkat dan daerah pelayanan, serta terget $3 \mathrm{R}$ dapat dilihat pada Tabel 4.

\section{Proyeksi Penduduk dan Proyeksi Timbulan Sampah}

menunjukkan metode yang tepat untuk proyeksi penduduk untuk semua kecamatan adalah metode eksponensial. Proyeksi total timbulan sampah domestik dapat dilihat dari jumlah kenaikan jumlah penduduk setiap tahunnya dengan satuan timbulan sampah Kota Bukittinggi sebesar 2,90 1/o/h, sementara untuk proyeksi timbulan sampah non domestik mengikuti proyeksi sampah domestik, persentase sampah non domestik berdasarkan kondisi eksisting adalah 32,6\% dari sampah domestik Kota Bukittinggi. Proyeksi penduduk dan timbulan sampah Kota Bukittinggi tahun 2015-2035 dapat dilihat pada Tabel 5.

Tabel 4. Rencana Kenaikan Persentase Daerah dan Tingkat Pelayanan Serta Target 3R per Zona

\begin{tabular}{|c|c|c|c|c|c|c|c|}
\hline \multirow[t]{2}{*}{ No } & \multirow[t]{2}{*}{ Zona } & \multirow{2}{*}{$\begin{array}{c}\text { Daerah } \\
\text { Pelayanan }\end{array}$} & \multirow{2}{*}{$\begin{array}{c}\text { Tingkat } \\
\text { Pelayanan }\end{array}$} & \multirow{2}{*}{$\begin{array}{c}\text { Interval Kenaikan } \\
\text { tingkat } \\
\text { Pelayanan/Tahun }\end{array}$} & \multicolumn{3}{|c|}{ Target 3R } \\
\hline & & & & & Total & $\begin{array}{c}\text { Sampah } \\
\text { Basah }\end{array}$ & $\begin{array}{c}\text { Sampah } \\
\text { Kering }\end{array}$ \\
\hline \multicolumn{8}{|c|}{ Eksisting } \\
\hline 1 & Zona I & $75,2 \%$ & $83,3 \%$ & 0 & 0 & 0 & 0 \\
\hline 2 & Zona II & $74,5 \%$ & $60 \%$ & 0 & 0 & 0 & 0 \\
\hline 3 & Zona III & $55 \%$ & $33,6 \%$ & 0 & 0 & 0 & 0 \\
\hline \multicolumn{8}{|c|}{ Jangka Pendek (2016-2020) } \\
\hline 1 & Zona I & $100 \%$ & $100 \%$ & 3,34 & $6 \%$ & $4,2 \%$ & $1,8 \%$ \\
\hline 2 & Zona II & $85 \%$ & $75 \%$ & 3 & $6 \%$ & $4,2 \%$ & $1,8 \%$ \\
\hline 3 & Zona III & $65 \%$ & $50 \%$ & 3,28 & $5 \%$ & $3,5 \%$ & $1,5 \%$ \\
\hline \multicolumn{8}{|c|}{ Jagka Menengah (2021-2025) } \\
\hline 1 & Zona I & $100 \%$ & $100 \%$ & 0 & $11 \%$ & $7,7 \%$ & $3,3 \%$ \\
\hline
\end{tabular}




\begin{tabular}{|cccccccc|}
\hline No & Zona & $\begin{array}{c}\text { Daerah } \\
\text { Pelayanan }\end{array}$ & $\begin{array}{c}\text { Tingkat } \\
\text { Pelayanan }\end{array}$ & $\begin{array}{c}\text { Interval Kenaikan } \\
\text { tingkat } \\
\text { Pelayanan/Tahun }\end{array}$ & & \multicolumn{3}{c|}{ Target 3R } \\
\cline { 7 - 8 } & & & & & $\begin{array}{c}\text { Sampah } \\
\text { Basah }\end{array}$ & $\begin{array}{c}\text { Sampah } \\
\text { Kering }\end{array}$ \\
\hline & & & & Eksisting & & & \\
\hline 1 & Zona I & $75,2 \%$ & $83,3 \%$ & 0 & 0 & 0 & 0 \\
\hline 2 & Zona II & $74,5 \%$ & $60 \%$ & 0 & 0 & 0 & 0 \\
\hline 3 & Zona III & $55 \%$ & $33,6 \%$ & 0 & 0 & 0 & 0 \\
\hline 2 & Zona II & $95 \%$ & $90 \%$ & 3 & $10 \%$ & $7 \%$ & $3 \%$ \\
\hline 3 & Zona III & $75 \%$ & $70 \%$ & 3 & & & \\
\hline & & & Jagka Panjang(2026-2035) & & & \\
\hline 1 & Zona I & $100 \%$ & $100 \%$ & 0 & $20 \%$ & $14 \%$ & $6 \%$ \\
\hline 2 & Zona II & $100 \%$ & $100 \%$ & 2 & $20 \%$ & $14 \%$ & $6 \%$ \\
\hline 3 & Zona III & $90 \%$ & $90 \%$ & 1 & $20 \%$ & $14 \%$ & $6 \%$ \\
\hline
\end{tabular}

Tabel 5 Proyeksi Penduduk dan Timbulan Sampah Kota Bukittinggi Tahun 2015-2035

\begin{tabular}{|c|c|c|c|c|c|c|c|c|c|}
\hline \multirow{2}{*}{ No } & \multirow{2}{*}{ Tahun } & \multicolumn{3}{|c|}{$\begin{array}{l}\text { Jumlah Penduduk perkecamatan } \\
\text { (jiwa) }\end{array}$} & \multirow{2}{*}{$\begin{array}{c}\text { Total } \\
\text { penduduk } \\
\text { (jiwa) }\end{array}$} & \multicolumn{3}{|c|}{ Timbulan Sampah $\left(\mathrm{m}^{3} / \mathrm{h}\right)$} & \multirow{2}{*}{$\begin{array}{c}\text { Total } \\
\text { Timbulan } \\
\text { Sampah } \\
\left(\mathrm{m}^{3} / \mathrm{h}\right)\end{array}$} \\
\hline & & GP & ABTB & MAKS & & GP & ABTB & MAKS & \\
\hline 1 & 2015 & 44945 & 27235 & 50306 & 122485 & 172,83 & 104,73 & 193,45 & 471,01 \\
\hline 2 & 2016 & 45745 & 27758 & 51449 & 124952 & 175,91 & 106,74 & 197,84 & 480,49 \\
\hline 3 & 2017 & 46560 & 28291 & 52618 & 127469 & 179,04 & 108,79 & 202,34 & 490,17 \\
\hline 4 & 2018 & 47389 & 28834 & 53813 & 130037 & 182,23 & 110,88 & 206,93 & 500,04 \\
\hline 5 & 2019 & 48233 & 29388 & 55036 & 132657 & 185,47 & 113,01 & 211,63 & 510,12 \\
\hline 6 & 2020 & 49092 & 29953 & 56286 & 135331 & 188,78 & 115,18 & 216,44 & 520,40 \\
\hline 7 & 2021 & 49966 & 30528 & 57565 & 138059 & 192,14 & 117,39 & 221,36 & 530,89 \\
\hline 8 & 2022 & 50856 & 31115 & 58872 & 140843 & 195,56 & 119,65 & 226,39 & 541,60 \\
\hline 9 & 2023 & 51762 & 31713 & 60210 & 143684 & 199,04 & 121,95 & 231,53 & 552,52 \\
\hline 10 & 2024 & 52683 & 32322 & 61577 & 146583 & 202,59 & 124,29 & 236,79 & 563,67 \\
\hline 11 & 2025 & 53622 & 32943 & 62976 & 149541 & 206,20 & 126,68 & 242,17 & 575,04 \\
\hline 12 & 2026 & 54577 & 33576 & 64407 & 152559 & 209,87 & 129,11 & 247,67 & 586,65 \\
\hline 13 & 2027 & 55549 & 34221 & 65870 & 155639 & 213,61 & 131,59 & 253,30 & 598,50 \\
\hline 14 & 2028 & 56538 & 34878 & 67366 & 158783 & 217,41 & 134,12 & 259,05 & 610,58 \\
\hline 15 & 2029 & 57545 & 35548 & 68897 & 161990 & 221,28 & 136,70 & 264,94 & 622,92 \\
\hline 16 & 2030 & 58570 & 36231 & 70462 & 165263 & 225,22 & 139,32 & 270,95 & 635,50 \\
\hline 17 & 2031 & 59613 & 36927 & 72063 & 168602 & 229,23 & 142,00 & 277,11 & 648,34 \\
\hline 18 & 2032 & 60674 & 37637 & 73700 & 172011 & 233,32 & 144,73 & 283,40 & 661,45 \\
\hline 19 & 2033 & 61755 & 38360 & 75374 & 175488 & 237,47 & 147,51 & 289,84 & 674,82 \\
\hline 20 & 2034 & 62855 & 39097 & 77086 & 179037 & 241,70 & 150,34 & 296,43 & 688,47 \\
\hline 21 & 2035 & 63974 & 39848 & 78837 & 182659 & 246,01 & 153,23 & 303,16 & 702,40 \\
\hline
\end{tabular}

Ket: GP : Kec. Guguk Panjang; ABTB: Aur Birugo Tigo BalehMAKS: Mandiangin Koto Selayan

\section{Perencanaan Target 3R Selama 20 Tahun}

Target 3R yang direncanakan pada studi pengembangangan pengelolaan sampah Kota Bukittinggi ini sebesar 20\% hingga akhir periode perencanaan, sesui dengan Permen PU No 03 Tahun 2013. Untuk persentase sampah basah (dikompos) dan sampah kering (didaur ulang) yang akan diolah masing-masing $70 \%$ dan $30 \%$ dari target $3 \mathrm{R}$ nya. Untuk rincian jumlah timbula sampah yang bisa diolah disetiap zona dapat dilihat pada Tabel 6. 2015 (eksisting).

\section{Perencanaan Sistem Pengelolaan Sampah}

1. Aspek Teknis
Target 3R yang direncanakan pada studi pengembangangan pengelolaan sampah Kota Bukittinggi ini sebesar 20\% hingga akhir periode perencanaan, sesui dengan Permen PU No 03 Tahun 2013. Untuk persentase sampah basah (dikompos) dan sampah kering (didaur ulang) yang akan diolah masing-masing $70 \%$ dan 30\% dari target 3R nya. Untuk rincian jumlah timbulan sampah yang bisa diolah disetiap zona dapat dilihat pada Tabel 6. 2015 (eksisting).

Perencanaan aspek teknis pengelolaan sampah Kota Bukittinggi secara umum adalah sebagai berikut: 
a. Sistem pewadahan

Sistem pewadahan yang direncanakan di sumber berupa pewadahan terpilah dan tercampur, untuk pewadahan terpilah diterapkan di kawasan yang memeiliki bangunan 3R, baik eksisting maupun yang direncanakan. Dengan sistem pemilahan terdiri dari sampah basah dan sampah kering. Dimana pada pengolahan sampah, sampah

b. Sistem pengumpulan

Sistem pengumpulan yang direncanakan pada pengembangan pengelolaan persampahan Kota Bukittinggi berupa pola individual tidak langsung (kawasan yang memiliki TPS 3R) untuk mengangkut sampah basah, komunal langsung untuk mengumpulkan sampah kering dalam bentuk bank sampah dan pola penyapuan jalan untuk mengumpulkan sampah jalan yang ada di jalan utama.

c. Sistem pengangkutan

Sistem pengangkutan yang direncanakan berupa sistem pengangkutan Hould Container System (HCS) hingga akhir periode perencanaan sementara untuk dump truck eksisting yang masih ada menggunakan sistem Stationary Conatiner System (SCS) hingga masa pakai dump truck habis.

d. Sistem pengolahan sampah

Pengolahan sampah yang direncanakan berupa pengolahan sampah skala kawasan dengan bangunan pengolahan berupa TPS 3R, sistem pengolahan yang dilakukan berupa pengomposan untuk sampah basah dan bank sampah untuk menampung sampah kering yang bisa di daur ulang seperti sampah plastik, karton dan kertas.

Tabel 6. Jumlah Volume Sampah Sampah yang masuk Ke TPS 3R

\begin{tabular}{|c|c|c|c|c|c|c|c|c|c|c|c|c|}
\hline \multirow[t]{2}{*}{ Tahun } & \multicolumn{3}{|c|}{ Targer 3R (\%) } & \multicolumn{9}{|c|}{ Volume sampah yang masuk ke TPS 3R $\left(\mathrm{m}^{3} / \mathrm{h}\right)$} \\
\hline & $\begin{array}{c}\text { Zona } \\
\text { I }\end{array}$ & $\begin{array}{c}\text { Zona } \\
\text { II }\end{array}$ & $\begin{array}{c}\text { Zona } \\
\text { III }\end{array}$ & $\begin{array}{c}\text { Sampa } \\
\text { h } \\
\text { Basah }\end{array}$ & $\begin{array}{c}\text { zona I } \\
\text { Sampah } \\
\text { Kering }\end{array}$ & $\begin{array}{c}\text { Total } \\
\text { Sampah }\end{array}$ & $\begin{array}{c}\text { Sampah } \\
\text { Basah }\end{array}$ & $\begin{array}{c}\text { zona II } \\
\text { Sampah } \\
\text { Kering }\end{array}$ & $\begin{array}{c}\text { Total } \\
\text { Sampah }\end{array}$ & $\begin{array}{c}\text { Sampa } \\
\mathrm{h} \\
\text { Basah }\end{array}$ & $\begin{array}{c}\text { zona III } \\
\text { Sampah } \\
\text { Kering }\end{array}$ & $\begin{array}{c}\text { Total } \\
\text { Sampa } \\
\mathrm{h}\end{array}$ \\
\hline 2015 & 0 & 0 & 0 & 0,00 & 0,00 & 0,00 & 0,00 & 0,00 & 0,00 & 0,00 & 0,00 & 0,00 \\
\hline 2016 & 2 & 5 & 0 & 0,00 & 0,00 & 0,00 & 2,35 & 1,01 & 3,36 & 0,00 & 0,00 & 0,00 \\
\hline 2017 & 3 & 5 & 2 & 3,38 & 1,45 & 4,83 & 2,51 & 1,08 & 3,59 & 1,15 & 0,49 & 1,64 \\
\hline 2018 & 4 & 6 & 3 & 4,76 & 2,04 & 6,79 & 3,21 & 1,38 & 4,59 & 1,90 & 0,81 & 2,71 \\
\hline 2019 & 5 & 6 & 4 & 6,26 & 2,68 & 8,95 & 3,42 & 1,46 & 4,88 & 2,78 & 1,19 & 3,97 \\
\hline 2020 & 6 & 6 & 5 & 7,91 & 3,39 & 11,30 & 3,63 & 1,55 & 5,18 & 3,79 & 1,62 & 5,41 \\
\hline 2021 & 6 & 6 & 5 & 8,05 & 3,45 & 11,51 & 3,85 & 1,65 & 5,49 & 4,18 & 1,79 & 5,98 \\
\hline 2022 & 7 & 7 & 6 & 9,56 & 4,10 & 13,66 & 4,75 & 2,04 & 6,78 & 5,51 & 2,36 & 7,88 \\
\hline 2023 & 8 & 8 & 7 & 11,12 & 4,77 & 15,89 & 5,74 & 2,46 & 8,19 & 7,03 & 3,01 & 10,05 \\
\hline 2024 & 10 & 9 & 8 & 14,15 & 6,07 & 20,22 & 6,81 & 2,92 & 9,73 & 8,75 & 3,75 & 12,50 \\
\hline 2025 & 11 & 10 & 10 & 15,85 & 6,79 & 22,64 & 7,98 & 3,42 & 11,40 & 11,87 & 5,09 & 16,95 \\
\hline 2026 & 11 & 10 & 10 & 16,13 & 6,91 & 23,04 & 8,22 & 3,52 & 11,75 & 12,48 & 5,35 & 17,83 \\
\hline 2027 & 13 & 12 & 11 & 19,40 & 8,31 & 27,71 & 10,17 & 4,36 & 14,53 & 14,43 & 6,19 & 20,62 \\
\hline 2028 & 14 & 13 & 12 & 21,26 & 9,11 & 30,38 & 11,35 & 4,86 & 16,22 & 16,54 & 7,09 & 23,63 \\
\hline 2029 & 15 & 13 & 13 & 23,19 & 9,94 & 33,13 & 11,69 & 5,01 & 16,70 & 18,81 & 8,06 & 26,86 \\
\hline 2030 & 16 & 14 & 14 & 25,17 & 10,79 & 35,96 & 12,97 & 5,56 & 18,53 & 21,24 & 9,10 & 30,35 \\
\hline 2031 & 17 & 15 & 15 & 27,22 & 11,67 & 38,89 & 14,31 & 6,13 & 20,45 & 23,86 & 10,23 & 34,08 \\
\hline 2032 & 18 & 16 & 16 & 29,34 & 12,57 & 41,91 & 15,72 & 6,74 & 22,46 & 26,66 & 11,43 & 38,09 \\
\hline 2033 & 19 & 17 & 17 & 31,52 & 13,51 & 45,03 & 17,20 & 7,37 & 24,57 & 29,66 & 12,71 & 42,37 \\
\hline 2034 & 20 & 18 & 18 & 33,77 & 14,47 & 48,24 & 18,75 & 8,04 & 26,79 & 32,87 & 14,09 & 46,95 \\
\hline 2035 & 20 & 20 & 20 & 34,37 & 14,73 & 49,10 & 21,45 & 9,19 & 30,65 & 38,20 & 16,37 & 54,57 \\
\hline
\end{tabular}

\section{e. TPA}

Tempat pemprosesan akhir yang direncanakan, masih menggunakan TPA Regional Payakumbuh hingga lahan TPA ini sudah penuh. Sistem yang digunakan pada TPA ini berupa sistem Sanitary Lanfill dengan pemanfaatan gas metan.
2) Aspek Peran Serta Masyarakat

Untuk mendukung sistem pengelolaan sampah dengan sistem 3R di Kota Bukittinggi direncanakan dengan menarik partisipasi masyarakat Kota Bukittinggi dengan cara melakukan sosialisasi 
mengenai Sistem Pengelolaan Sampah dengan 3R di lembaga-lembaga pendidikan serta memberi sosialisasi-sosialisasi mengenai bank sampah yang merupakan salah satu strategi penerapan 3R dalam pengelolaan sampah di tingkat masyarakat. dengan prinsip rekayasa sosial (social engineering) untuk mengajak masyarakat memilah sampah dan menabungnya di Bank sampah yang ada di setiap TPS 3R perencanaan. Pada aktivitas pengolahan sampah masyarakat sangat diharapkan dapat memilah sampah di sumber, kemudian diharapkan adanya KSM yang dapat mengelola TPS 3R yang direncanakan di setiap zona pengembangan.

\section{PROGRAM PENGEMBANGAN}

\section{Jumlah Pewadahan}

Sarana pewadahan sampah Kota Bukittinggi ini terdiri dari sarana pewadahan individual dan komunal. Pewadahan individual direncanakan disediakan oleh masing-masing masyarakat. Untuk masyarakat yang memiliki bangunan pengolahan sampah, maka dilakukan pemilahan sampah menjadi sampah basah dan sampah kering. Namun untuk daerah yang tidak memiliki maka sampah tercampur yang ditampung ke pewadahan komunal berupa Kontainer $6 \mathrm{~m}^{3}$ dan $8 \mathrm{~m}^{3}$. Penggunaan kontainer $6 \mathrm{~m}^{3}$ hanya digunakan hingga masa pakai kontainer eksisting habis sebanyak 13 buah. Selanjutnya dilakukan pemusnahan TPS kayu dan batu, karena tidak sesuai dengan SNI 192454-2002.

Tabel 7. Jumlah Pewadahan Komunal yang dibutuhkan di Kota Bukittinggi

\begin{tabular}{|c|c|c|c|c|c|c|}
\hline \multirow{4}{*}{$\begin{array}{c}\text { Tahu } \\
\mathrm{n}\end{array}$} & \multicolumn{6}{|c|}{ Kebutuhan Kontainer } \\
\hline & \multicolumn{3}{|c|}{$\begin{array}{c}\text { Sampah langsung ke } \\
\text { TPA }\end{array}$} & \multicolumn{3}{|c|}{ Kontiner Residu } \\
\hline & Zona & Zona & Zona & Zona & Zona & Zona \\
\hline & I & II & III & I & II & III \\
\hline $2015 *$ & 0 & 0 & 0 & 0 & 0 & 0 \\
\hline 2020 & 10 & 10 & 13 & 1 & 1 & 1 \\
\hline 2025 & 23 & 13 & 19 & 2 & 2 & 2 \\
\hline 2035 & 25 & 15 & 28 & 4 & 4 & 4 \\
\hline
\end{tabular}

*Eksisting

Pewadahan komunal ini digunakan untuk menampung sampah yang langsung diangkut ke TPA dengan sistem tercampur dan juga mengangkut sampah residu yang berada di TPS
3R. Jumlah sarana pewadahan sampah yang dibutuhkan dapat dilihat Tabel 7.

Tabel 8. Kebutuhan Becak Motor

\begin{tabular}{|c|c|c|c|c|c|c|c|}
\hline \multirow{3}{*}{$\begin{array}{c}\text { Tah } \\
\text { un }\end{array}$} & \multicolumn{6}{|c|}{ Kebutuhan Becak motor } & \multirow{3}{*}{$\begin{array}{l}\text { Tot } \\
\text { al } \\
\text { (un } \\
\text { it) }\end{array}$} \\
\hline & \multicolumn{3}{|c|}{ Sampah basah } & \multicolumn{3}{|c|}{ Sampah kering } & \\
\hline & $\begin{array}{c}\text { Zon } \\
\text { a I }\end{array}$ & $\begin{array}{l}\text { Zon } \\
\text { a II }\end{array}$ & $\begin{array}{c}\text { Zona } \\
\text { III }\end{array}$ & $\begin{array}{c}\text { Zon } \\
\text { a I }\end{array}$ & $\begin{array}{c}\text { Zon } \\
\text { a II }\end{array}$ & $\begin{array}{c}\text { Zona } \\
\text { III }\end{array}$ & \\
\hline 201 & & & & & & & \\
\hline $5 *$ & 3 & 4 & 2 & 1 & 2 & 1 & 13 \\
\hline 201 & & & & & & & \\
\hline 6 & 3 & 4 & 2 & 1 & 2 & 1 & 13 \\
\hline 201 & & & & & & & \\
\hline 7 & 3 & 4 & 2 & 1 & 2 & 1 & 13 \\
\hline 201 & & & & & & & \\
\hline 8 & 3 & 5 & 2 & 1 & 2 & 1 & 14 \\
\hline 201 & & & & & & & \\
\hline 9 & 3 & 5 & 2 & 1 & 2 & 1 & 14 \\
\hline 202 & & & & & & & \\
\hline 0 & 3 & 5 & 2 & 1 & 2 & 1 & 14 \\
\hline 202 & & & & & & & \\
\hline 1 & 3 & 5 & 4 & 1 & 2 & 2 & 17 \\
\hline 202 & & & & & & & \\
\hline 2 & 6 & 5 & 4 & 2 & 2 & 2 & 21 \\
\hline 202 & & & & & & & \\
\hline 3 & 6 & 5 & 4 & 2 & 2 & 2 & 21 \\
\hline 202 & & & & & & & \\
\hline 4 & 6 & 5 & 4 & 2 & 2 & 2 & 21 \\
\hline 202 & & & & & & & \\
\hline 5 & 6 & 5 & 4 & 2 & 2 & 1 & 20 \\
\hline 202 & & & & & & & \\
\hline 6 & 6 & 5 & 4 & 2 & 2 & 1 & 20 \\
\hline 202 & & & & & & & \\
\hline 7 & 6 & 5 & 4 & 2 & 2 & 1 & 20 \\
\hline 202 & & & & & & & \\
\hline 8 & 6 & 5 & 4 & 2 & 2 & 1 & 20 \\
\hline 202 & & & & & & & \\
\hline 9 & 8 & 5 & 4 & 2 & 2 & 1 & 22 \\
\hline 203 & & & & & & & \\
\hline 0 & 8 & 5 & 4 & 2 & 2 & 1 & 22 \\
\hline 203 & & & & & & & \\
\hline 1 & 9 & 5 & 8 & 2 & 2 & 2 & 28 \\
\hline 203 & & & & & & & \\
\hline 2 & 9 & 5 & 8 & 2 & 2 & 2 & 28 \\
\hline 203 & & & & & & & \\
\hline 3 & 9 & 5 & 8 & 2 & 2 & 2 & 28 \\
\hline 203 & & & & & & & \\
\hline 4 & 9 & 6 & 9 & 2 & 2 & 2 & 30 \\
\hline 203 & & & & & & & \\
\hline 5 & 9 & 6 & 10 & 2 & 2 & 2 & 31 \\
\hline
\end{tabular}

*eksisting

\section{Jumlah Sarana Pengumpulan}

Sarana pengumpulan sampah yang digunakan untuk pola ini berupa gerobak sampah, becak sampah dan becak motor. Volume sampah yang diangkut berasal dari kelurahan yang memiliki TPS, sampah yang diangkut dengan becak motor ke kontainer yaitu sampah basah dan kering. Untuk alat kumpul yang menuju ke TPS 3R hanya mengangkut sampah basah saja, karena sampah kering langsung di antar ke TPS 3R (menabung sampah). Jumlah sarana yang 
dibutuhkan untuk pola individual tidak langsung dan penyapuan jalan dapat dilihat pata Tabel 8.

Sarana yang dibutuhkan untuk pola penyapuan jalan ini berupa gerobak sampah yang dibawa pada saat penyapuan jalan dilaksanakan. Berdasarkan volume sampah jalan eksisting, persentase sampah jalan terhadap sampah volume sampah total adalah $0,69 \%$. jumlah sarana yang dibutuhkan untuk penyapuan jalan dapat dilihat pata Tabel 9. Jumlah Sarana

\section{Pengangkutan}

Tabel 9. Kebutuhan Gerobak Sampah

\begin{tabular}{|ccccc|}
\hline \multirow{2}{*}{$\begin{array}{c}\text { Tahu } \\
\mathrm{n}\end{array}$} & \multicolumn{3}{c}{ Kebutuhan Gerobak sampah } & Total \\
\cline { 2 - 4 } & I & Zona & Zona III & (unit \\
\hline 2015 & 1 & 1 & 1 & 3 \\
\hline 2016 & 1 & 1 & 1 & 3 \\
\hline 2017 & 1 & 1 & 1 & 3 \\
\hline 2018 & 1 & 1 & 1 & 3 \\
\hline 2019 & 1 & 1 & 1 & 3 \\
\hline 2020 & 1 & 1 & 1 & 3 \\
\hline 2021 & 2 & 1 & 1 & 4 \\
\hline 2022 & 2 & 1 & 1 & 4 \\
\hline 2023 & 2 & 1 & 1 & 4 \\
\hline 2024 & 2 & 1 & 1 & 4 \\
\hline 2025 & 2 & 1 & 1 & 4 \\
\hline 2026 & 2 & 1 & 2 & 5 \\
\hline 2027 & 2 & 1 & 2 & 5 \\
\hline 2028 & 2 & 1 & 2 & 5 \\
\hline 2029 & 2 & 1 & 2 & 5 \\
\hline 2030 & 2 & 1 & 2 & 5 \\
\hline 2031 & 2 & 1 & 2 & 5 \\
\hline 2032 & 2 & 1 & 2 & 5 \\
\hline 2033 & 2 & 1 & 2 & 5 \\
\hline 2034 & 2 & 1 & 2 & 5 \\
\hline 2035 & 2 & 1 & 2 & 5 \\
\hline
\end{tabular}

Rancangan Sistem pengangkutan sampah yang berbasis $3 \mathrm{R}$ direncanakan pengangkutan sampah dngan menggunakan Dump Truck dan Amroll Truck dengan jumlah ritasi 2-3 kali dalam 1 hari. Sistem pengangkutan yang direncanakan yaitu mengangkut sampah dari TPS ke TPA dan residu sampah di TPS 3R ke TPA. Jumlah residu sampah yang tidak terlalu banyak, maka dikhususkan pada saat volume kontainer di TPS 3R sudah penuh maka terdapat satu atau dua truk sampah yang mengangkut sampah dengan ritasi 3 kali dalam 1 hari. Jumlah Truck yang dibutuhkan di setiap zona sampai akhir periode jangka panjang dapat di lihat pada Tabel 10.

Tabel 10. Kebutuhan Truk Sampah

\begin{tabular}{|c|c|c|c|c|c|c|}
\hline \multirow{3}{*}{ Tahun } & \multicolumn{4}{|c|}{ Jumlah Amroll Truck(buah) } & \multirow{3}{*}{$\begin{array}{c}\text { Juml } \\
\text { ah } \\
\text { Rita } \\
\text { si* }\end{array}$} & \multirow{3}{*}{$\begin{array}{c}\text { Tota } \\
1 \\
\text { Truc } \\
\text { k }\end{array}$} \\
\hline & $\begin{array}{c}\text { Dump } \\
\text { Truck } 8\end{array}$ & \multicolumn{3}{|c|}{ Amroll Truck $8 \mathrm{~m}^{3}$} & & \\
\hline & Zona I & $\begin{array}{c}\text { Zona } \\
\text { I }\end{array}$ & $\begin{array}{c}\text { Zo } \\
\text { na } \\
\text { II }\end{array}$ & $\begin{array}{l}\text { Zo } \\
\text { na } \\
\text { III }\end{array}$ & & \\
\hline 2015 & 7 & 0 & 0 & 0 & 2 & 7 \\
\hline 2016 & 7 & 4 & 4 & 5 & 2 & 20 \\
\hline 2017 & 7 & 4 & 4 & 5 & 2 & 20 \\
\hline 2018 & 7 & 4 & 5 & 5 & 2 & 21 \\
\hline 2019 & 7 & 4 & 5 & 6 & 2 & 22 \\
\hline 2020 & 5 & 5 & 5 & 7 & 2 & 22 \\
\hline 2021 & 4 & 8 & 6 & 7 & 2 & 25 \\
\hline 2022 & 2 & 9 & 6 & 8 & 2 & 25 \\
\hline 2023 & 2 & 9 & 6 & 9 & 2 & 26 \\
\hline 2024 & 0 & 12 & 6 & 9 & 2 & 27 \\
\hline 2025 & 0 & 12 & 7 & 10 & 2 & 29 \\
\hline 2026 & 0 & 12 & 7 & 10 & 2 & 29 \\
\hline 2027 & 0 & 12 & 7 & 11 & 2 & 30 \\
\hline 2028 & 0 & 12 & 7 & 11 & 2 & 30 \\
\hline 2029 & 0 & 12 & 7 & 12 & 2 & 31 \\
\hline 2030 & 0 & 12 & 7 & 12 & 2 & 31 \\
\hline 2031 & 0 & 12 & 7 & 12 & 2 & 31 \\
\hline 2032 & 0 & 12 & 8 & 13 & 2 & 33 \\
\hline 2033 & 0 & 12 & 8 & 13 & 2 & 33 \\
\hline 2034 & 0 & 12 & 8 & 14 & 2 & 34 \\
\hline 2035 & 0 & 13 & 8 & 14 & 2 & 35 \\
\hline
\end{tabular}

*Terdapat dua atau lebih truck dengan jumlah ritasi tiga untuk mengangkut jumlah residu di TPS $3 R$

2015,Tahun eksisting ***tahun pengandaan dumptruck

eksisting, 2 buah-2012, 3 buah 2013, dan 2 buah 2014

\section{Sistem Pengolahan Sampah}

Tempat Pengolahan Sampah (TPS) 3R yang direncanakan akan dikelola oleh kelompok swadaya masyarakat yang akan di monitoring oleh DKP Kota Bukitinggi. TPS 3R yang drencanakan terdiri dari 3 Tipe yang memiliki perbedaan dari luas dan pelayanan TPS 3R tersebut, menimbang meningkatnya tingkat pelayanan dan target $3 \mathrm{R}$ yang direncanakan sehingga menyebabkan meningkatnya volume sampah yang akan diolah. Perhitungan rincian luas TPS 3R dapat dilihat pada Lampiran LDIX. Rincian dari ketiga TPS 3R yaitu:

1. Tipe I

Beban penerimaan total TPS 3R tipe ini adalah $6 \mathrm{~m}^{3} /$ hari atau melayani sekitar $\pm 400 \mathrm{KK}$ yang masih berada disatu kelurahan. Beban sampah basah sebesar $4 \mathrm{~m}^{3} /$ hari dan sampah kering 2 $\mathrm{m}^{3} /$ hari. Sampah basah diolah menjadi kompos 
dengan metode pengomposan takakura susun, lama pengomposan 14 hari. Pemilihan metode pengomposan ini karena metode ini dapat menghemat lahan, selain itu proses composting berlangsung cepat, proses rapi dan sangat terstruktur. Sementara untuk sampah kering yang terdiri dari sampah daur ulang yang akan dituangkan dalam bentuk bank sampah dengan jumlah nasabah $\pm 400 \mathrm{KK}$ yang terlayani oleh TPS 3R tipe ini.

Tabel 11. Perbandingan TPS 3R Tipe I, II dan III

\begin{tabular}{|c|c|c|c|}
\hline Aspek & Tipe I & Tipe II & $\begin{array}{l}\text { Tipe } \\
\text { III }\end{array}$ \\
\hline 1. Luas total $\left(\mathrm{m}^{2}\right)$ & 209 & 402,5 & 494 \\
\hline 2. Jumlah KK & 400 & 800 & 1600 \\
\hline 3. Beban layanan $\left(\mathrm{m}^{3}\right)$ & 6 & 13 & 23 \\
\hline 4. Jenis komposter & $\begin{array}{r}\text { Takakur } \\
\text { a susun }\end{array}$ & $\begin{array}{r}\text { Takakura } \\
\text { susun } \\
\end{array}$ & $\begin{array}{r}\text { Rotary } \\
\text { kiln } \\
\end{array}$ \\
\hline 5. Jumlah komposter & 2 & 5 & 7 \\
\hline $\begin{array}{l}\text { 6. Ruang pencurahan dan } \\
\text { pemilahan sampah } \\
\text { Basah }\left(\mathrm{m}^{2}\right)\end{array}$ & 24 & 44 & 50 \\
\hline $\begin{array}{l}\text { 7. Ruang pencacahan } \\
\text { sampah basah }\left(\mathrm{m}^{2}\right)\end{array}$ & 14 & 15 & 28 \\
\hline 8. $\begin{array}{l}\text { Ruang pengomposan } \\
\left(\mathrm{m}^{2}\right)\end{array}$ & 44,4 & 81 & 120 \\
\hline $\begin{array}{ll}\text { 9. } & \text { Ruang pengayakan } \\
\text { kompos }\left(\mathrm{m}^{2}\right)\end{array}$ & 9 & 12 & 12 \\
\hline $\begin{array}{l}10 \text { Ruang pengemasan } \\
\text { kompos }\left(\mathrm{m}^{2}\right)\end{array}$ & 12 & 12 & 12 \\
\hline 11 Bank sampah $\left(\mathrm{m}^{2}\right)$ & 6 & 6 & 6 \\
\hline $\begin{array}{l}12 \text { Ruang pencucian dan } \\
\text { pengemasan sampah } \\
\text { kering daur ulang }\left(\mathrm{m}^{2}\right)\end{array}$ & 12 & 20 & 22 \\
\hline $\begin{array}{l}13 \text { Gudang penyimpanan } \\
\text { kompos dan sampah } \\
\text { daur ulang }\left(\mathrm{m}^{2}\right)\end{array}$ & 8,5 & 18 & 30 \\
\hline $\begin{array}{l}14 \text { Lahan penampungan } \\
\text { residu sampah }\left(\mathrm{m}^{2}\right)\end{array}$ & 6 & 6 & 6 \\
\hline $\begin{array}{l}15 \text { Ruang kantor dan pos } \\
\text { jaga }\left(\mathrm{m}^{2}\right)\end{array}$ & 10,5 & 14 & 12 \\
\hline
\end{tabular}

2. Tipe II

TPS 3R tipe ini menyesuaikan dengan luas eksisting bangunan pengolahan sampah yang ada. Dengan beban penerimaan total $13 \mathrm{~m}^{3} /$ hari atau melayani sekitar $\pm 800 \mathrm{KK}$ yang berada masih disatu kelurahan. Beban sampah basah sebesar $9 \mathrm{~m}^{3} /$ hari dan sampah kering $4 \mathrm{~m}^{3} /$ hari. Sampah basah diolah menjadi kompos dengan metode pengomposan takakura susun, lama pengomposan 14 hari. Sementara untuk sampah kering yang terdiri dari sampah daur ulang yang akan dituangkan dalam bentuk bank sampah dengan jumlah nasabah \pm 800 KK yang terlayani oleh TPS 3R tipe ini.

\section{Tipe III}

TPS 3R tipe ini menyesuaikan dengan luas eksisting bangunan pengolahan sampah yang ada. Dengan beban penerimaan total $23 \mathrm{~m}^{3} / \mathrm{hari}$ atau melayani sekitar $\pm 1600 \mathrm{KK}$ yang berada masih disatu kelurahan. Beban sampah basah sebesar $16 \mathrm{~m}^{3} /$ hari dan sampah kering $7 \mathrm{~m}^{3} /$ hari. Sampah basah diolah menjadi kompos dengan metode pengomposan Rotary Kiln, lama pengomposan 7 hari dengan penambahan bakteri. Pemilihan metode pengomposan ini karena pada metode ini tidak memerlukan lahan yang luas, cepat, hiegenis, bersih dan tidak mengganggu lingkungan dengan bau, selain itu komposter jenis ini memiliki kapasitas yang cukup besar. Sementara untuk sampah kering yang terdiri dari sampah daur ulang yang akan dituangkan dalam bentuk bank sampah dengan jumlah nasabah $\pm 1600 \mathrm{KK}$. Perbandingan rincian spesifikasi TPS 3R tipe I, II dan III dapat dilihat pada Tabel 11. Direncanakan pengolahan sampah yang akan dilakukan berupa kegiatan pengomposan dan daur ulang sampah. Untuk perencanaan pembangunan TPS 3R dapat dilihat pada Tabel 12 dan Gambar 4. Perencanaan pembangunan dilakukan menimbang tidak tertampung lagi sampah yang diolah di TPS yang sudah ada sementara target $3 \mathrm{R}$ yang terus meningkat.

Tabel 12. Rencana Lokasi TPS 3R Kota Bukittinggi

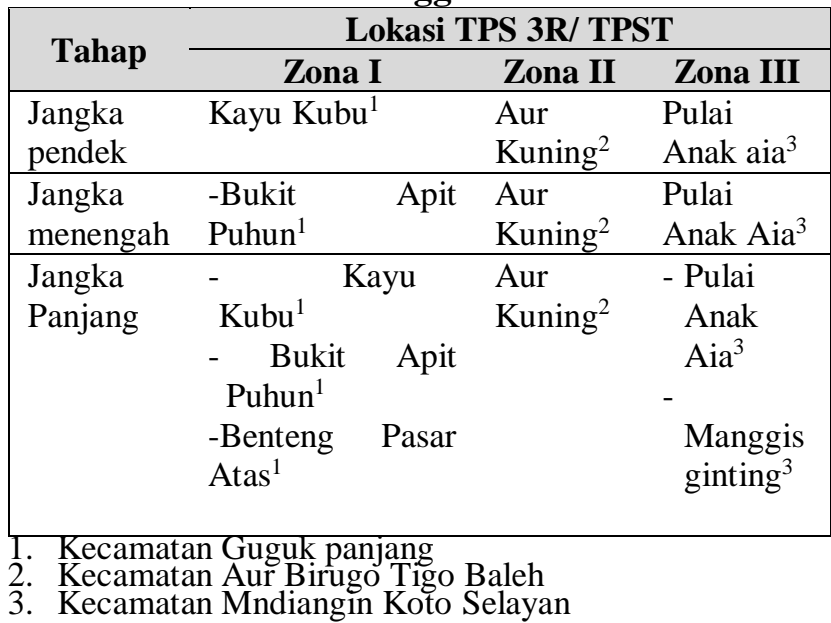




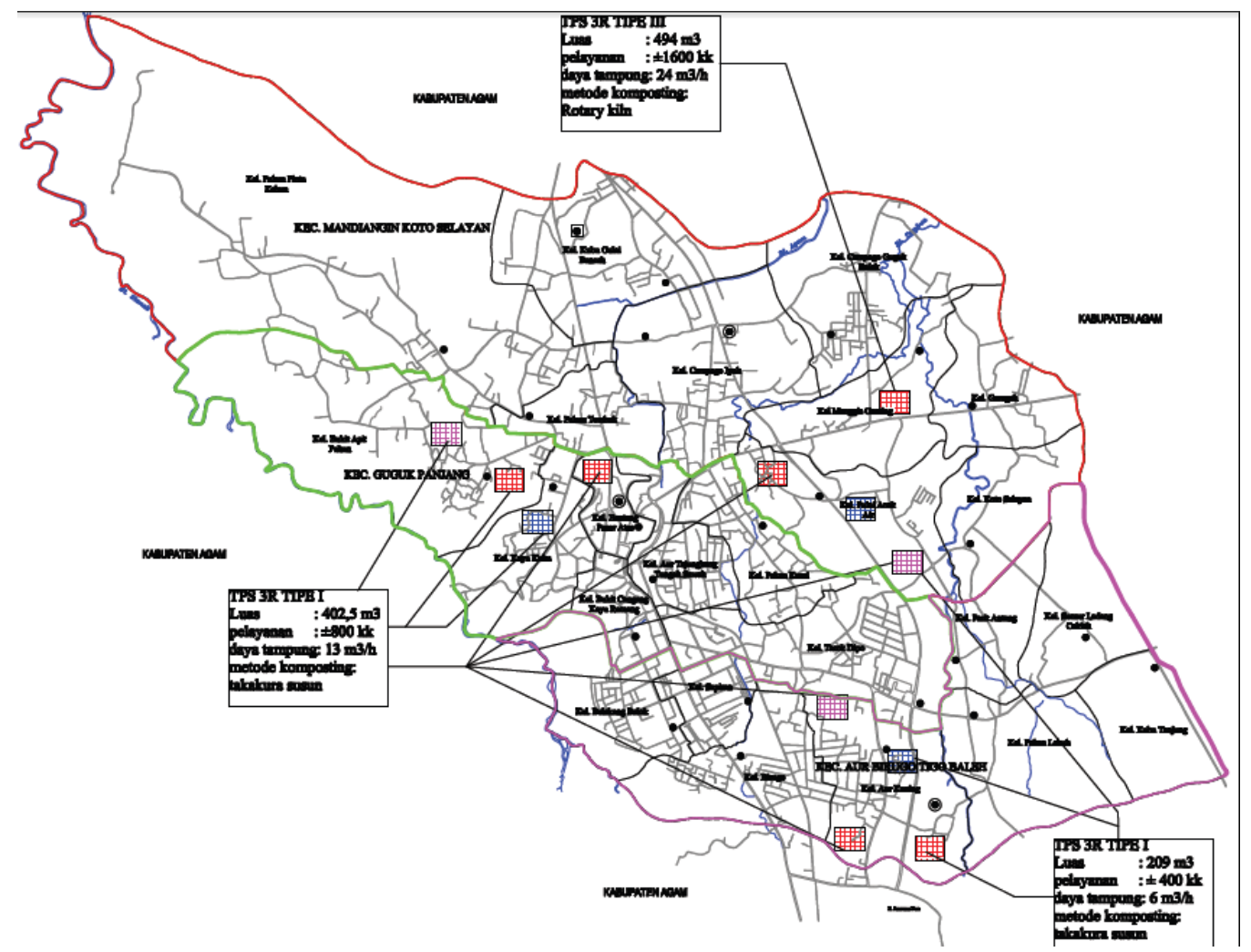

GAMBAR 4. Peta Perletakan TPS 3R Kota Bukittinggi hingga akhir periode perencanaan

Tabel 13. Perencanaan Pembangunan TPS 3R

\begin{tabular}{|llllllllll|}
\hline \multirow{2}{*}{ Tahap } & \multicolumn{3}{c}{ Perencanaan pembangunan } & \multicolumn{2}{c|}{ Tahun Pembangunan } & \multicolumn{3}{c|}{ Tahun Operasional } \\
\cline { 2 - 9 } & Zona I & Zona II & Zona III & $\begin{array}{c}\text { Zona } \\
\text { I }\end{array}$ & $\begin{array}{c}\text { Zona } \\
\text { II }\end{array}$ & $\begin{array}{c}\text { Zona } \\
\text { III }\end{array}$ & $\begin{array}{c}\text { Zona } \\
\text { I }\end{array}$ & $\begin{array}{c}\text { Zona } \\
\text { II }\end{array}$ & $\begin{array}{c}\text { Zona } \\
\text { III }\end{array}$ \\
\hline $\begin{array}{l}\text { Jangka } \\
\text { Pendek }\end{array}$ & $\begin{array}{l}\text { 1 TPS 3R } \\
\text { tipe II }\end{array}$ & $\begin{array}{l}\text { 1 TPS 3R } \\
\text { tipe I }\end{array}$ & $\begin{array}{l}\text { 1 TPS 3R } \\
\text { Tipe I }\end{array}$ & 2016 & 2016 & 2016 & 2017 & 2016 & 2017 \\
\hline $\begin{array}{l}\text { Jangka } \\
\text { menengah }\end{array}$ & $\begin{array}{l}\text { T TPS 3R } \\
\text { Tipe II }\end{array}$ & $\begin{array}{l}\text { 1 TPS 3R } \\
\text { tipe I }\end{array}$ & $\begin{array}{l}\text { 1 TPS 3R } \\
\text { tipe II }\end{array}$ & 2021 & 2021 & 2021 & 2022 & 2024 & 2023 \\
\hline $\begin{array}{l}\text { Jangka } \\
\text { Panjang }\end{array}$ & $\begin{array}{l}\text { 1 TPS 3R } \\
\text { Tipe II }\end{array}$ & $\begin{array}{l}\text { tips I } \\
\text { Tip }\end{array}$ & $\begin{array}{l}\text { 1 TPS 3R } \\
\text { tipe II }\end{array}$ & 2026 & 2026 & 2026 & 2027 & 2027 & 2027 \\
& $\begin{array}{l}\text { 1 TPS 3R } \\
\text { Tipe II }\end{array}$ & $\begin{array}{l}\text { 1 TPS 3R } \\
\text { Tipe II }\end{array}$ & $\begin{array}{l}\text { 1 TPS 3R } \\
\text { Tipe III }\end{array}$ & 2031 & 2031 & 2031 & 2032 & 2031 & 2031 \\
\hline
\end{tabular}

\section{Mass Balance}

Mass Balance pengelolaan sampah Kota Bukittinggi dapat dilihat pada Gambar 5. dan Gambar 6. Tujuan mass balance ini adalah untuk mengetahui jumlah sampah total yang terlayani, yang masuk ke lokasi pengolahan dan sampah yang langsung masuk ke TPA.Berdasarakan jumlah timbulan sampah yang langsung ke TPA diatas dihitung luas kebutuhan TPA per Tahun selama 20 Tahun perencanaan dengan Rumus yang ditetapkan oleh DPU (2006). Kebutuhan luas TPA selama 20 Tahun dapat dilihat pada Tabel 14. Berdasarakan Tabel 14 tersebut Luas TPA
Regional yang diperuntukkan untuk Kota Bukittinggi hanya cukup untuk menampung sampah hingga tahun 2029 (awal jangka panjang) Sehingga dibutuhkan lahan baru sebagai TPA untuk menampung sampah hingga akhir periode perencanaan. Untuk itu diperlukan program dan kegiatan untuk dapat mencari lokasi TPA baru agar sampah Kota Bukittinggi dapat tertampung sebelum penutupan TPA Regional. 


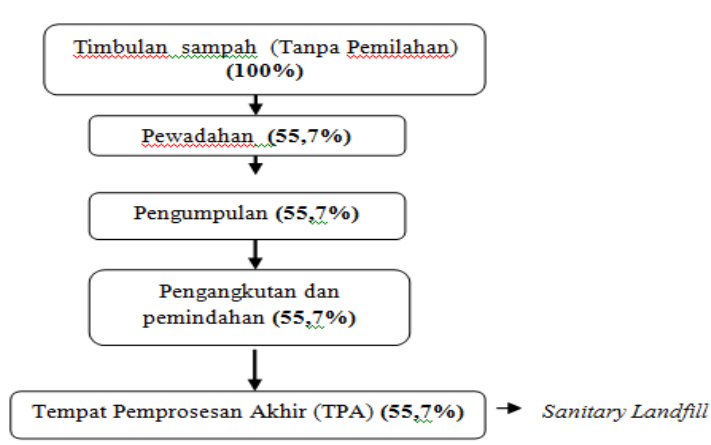

Gambar 5. Mass Balance Eksisting

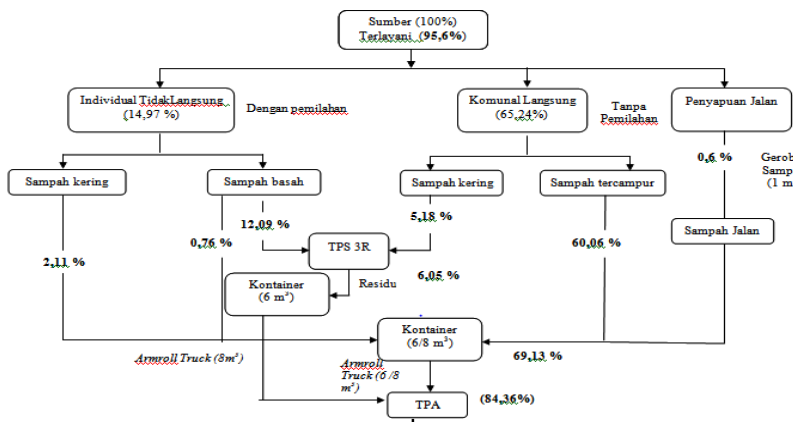

Gambar 5. Mass Balance Kota Bukittinggi Akhir Prencanaan (2035)

Tabel 14. Luas Kebutuhan TPA Per Tahun selama 20 Tahun

\begin{tabular}{|cccccc|}
\hline Tahun & $\begin{array}{c}\text { Jumlah } \\
\text { Sampah } \\
\text { ke TPA } \\
\left(\mathrm{m}^{3} / \mathrm{h}\right)\end{array}$ & $\begin{array}{c}\text { Volume } \\
\text { terpadatk } \\
\text { an }\end{array}$ & $\begin{array}{c}\text { Tinggi } \\
\text { timbunan } \\
\text { rencana }\end{array}$ & $\begin{array}{c}\text { Luas } \\
\text { yang } \\
\text { dibutuh } \\
\text { kan } \\
\text { (Ha) }\end{array}$ & $\begin{array}{c}\text { Akumula } \\
\text { si } \\
\text { Kebtuhan } \\
\text { Lahan } \\
(\text { Ha })\end{array}$ \\
\hline $2015^{*}$ & 271,80 & 226,50 & 10 & 0,55 & 0,55 \\
\hline 2016 & 291,31 & 242,76 & 10 & 0,59 & 1,13 \\
\hline 2017 & 307,74 & 256,45 & 10 & 0,62 & 1,75 \\
\hline 2018 & 327,57 & 272,97 & 10 & 0,66 & 2,41 \\
\hline 2019 & 347,91 & 289,92 & 10 & 0,70 & 3,11 \\
\hline 2020 & 368,77 & 307,31 & 10 & 0,74 & 3,85 \\
\hline 2021 & 387,92 & 323,27 & 10 & 0,78 & 4,63 \\
\hline 2022 & 404,98 & 337,48 & 10 & 0,82 & 5,45 \\
\hline 2023 & 422,44 & 352,03 & 10 & 0,85 & 6,30 \\
\hline 2024 & 191,99 & 159,99 & 10 & 0,39 & 6,69 \\
\hline 2025 & 258,13 & 215,11 & 10 & 0,52 & 7,21 \\
\hline 2026 & 271,31 & 226,09 & 10 & 0,55 & 7,75 \\
\hline 2027 & 314,54 & 262,12 & 10 & 0,63 & 8,38 \\
\hline 2028 & 359,95 & 299,96 & 10 & 0,72 & 9,11 \\
\hline 2029 & 408,39 & 340,32 & 10 & 0,82 & 9,93 \\
\hline 2030 & 460,91 & 384,09 & 10 & 0,93 & 10,86 \\
\hline 2031 & 517,26 & 431,05 & 10 & 1,04 & 11,90 \\
\hline 2032 & 544,68 & 453,90 & 10 & 1,10 & 13,00 \\
\hline 2033 & 558,02 & 465,01 & 10 & 1,12 & 14,12 \\
\hline 2034 & 571,60 & 476,33 & 10 & 1,15 & 15,27 \\
\hline 2035 & 584,26 & 486,88 & 10 & 1,18 & 16,45 \\
\hline Total & & & & & 16,45 \\
\hline & & & & & \\
\hline
\end{tabular}

Analisis Perbandingan (Konvesional vs Sistem 3R

1. Sarana pewadahan

Berdasarakan proyeksi timbulan sampah dengan tingkat pelayanan dan terget $3 \mathrm{R}$ yang direncanakan, perbandingan kebutuhan wadah Komunal dengan sistem konvesional dan sistem 3R dapat dilihat Tabel 15.

Berdasarkan Tabel 15, dapat dilihat ada perbedaan jumlah wadah yang dibutuhkan pada sistem Konvesional dan sistem 3R, dimana dengan adanya sistem pengolahan 3R, kebutuhan wadah komunal juga berkurang.

Tabel 15. Jumlah Wadah yang dibutuhkan dengan Sistem Konvensional Vs sistem 3R

\begin{tabular}{|c|c|c|c|}
\hline \multirow{3}{*}{ Tahap } & \multirow{3}{*}{$\begin{array}{l}\text { Timbulan } \\
\text { sampah } \\
\text { Kota } \\
\text { Terlayani } \\
(\mathrm{m} 3 / \mathrm{h})\end{array}$} & \multicolumn{2}{|c|}{$\begin{array}{l}\text { Jumlah Pewadahan } \\
\text { Komunal }\end{array}$} \\
\hline & & $\begin{array}{c}\text { Konvesiona } \\
1\end{array}$ & Sistem 3R \\
\hline & & $\begin{array}{c}\text { Kontainer } 8 \\
\text { m3 }\end{array}$ & $\begin{array}{c}\text { Kontainer } 8 \\
\mathrm{~m} 3^{*}\end{array}$ \\
\hline \multicolumn{4}{|l|}{ Jangka } \\
\hline Pendek & 383,38 & 48 & 36 \\
\hline \multicolumn{4}{|l|}{ Jangka } \\
\hline Menengah & 489,73 & 61 & 59 \\
\hline \multicolumn{4}{|l|}{ Jangka } \\
\hline Panjang & 672,08 & 84 & 80 \\
\hline
\end{tabular}

2. Sarana Pengumpulan dan Pengangkutan Perbandingan Jumlah kebutuhan sarana pengumpulan dan pengangkutan sampah dengan sistem konvesional dan 3R dapat dilihat pada Tabel 16.

3. Sarana Pengumpulan dan Pengangkutan Perbandingan Jumlah kebutuhan sarana pengumpulan dan pengangkutan sampah dengan sistem konvesional dan $3 \mathrm{R}$ dapat dilihat pada Tabel 16. 
Tabel 16.Kebutuhan Sarana Pengumpulan dan Pengangkutan Sistem Konesional Vs sistem 3R

\begin{tabular}{|c|c|c|c|c|c|}
\hline \multirow[b]{3}{*}{ Tahap } & \multirow{3}{*}{$\begin{array}{l}\text { Jumlah } \\
\text { Timbulan } \\
\text { Sampah } \\
\text { Kota } \\
\text { Terlayani } \\
\left(\mathrm{m}^{3} / \mathrm{h}\right)\end{array}$} & \multicolumn{2}{|c|}{ Jumlah Sarana Pengumpulan } & \multicolumn{2}{|c|}{ Sarana Pengangkutan } \\
\hline & & Konvesional & Sistem 3R & Konvesional & Sistem 3R \\
\hline & & Becak Motor & $\begin{array}{l}\text { Becak } \\
\text { Motor* }\end{array}$ & $\begin{array}{c}\text { Amroll } \\
\text { Truck }\end{array}$ & $\begin{array}{c}\text { Amroll } \\
\text { Truck** }\end{array}$ \\
\hline Jangka Pendek & 383,38 & 85 & 14 & 24 & 22 \\
\hline Jangka & & & & & \\
\hline Menengah & 489,73 & 109 & $\frac{20}{31}$ & $\frac{31}{42}$ & $\frac{29}{35}$ \\
\hline Jangka Panjang & 672,08 & 149 & 31 & 42 & 35 \\
\hline
\end{tabular}

\section{*Rekapitulasi jumlah becak motor pada Tabel 8 \\ *Rekapitulasi jumlah Truk pada Tabel 10}

Berdasarkan Tabel di atas dapat dilihat perbandingan jumlah sarana pengumpul dengan sistem konvesional lebih banyak menggunakan becak motor dibandingkan dengan sistem $3 \mathrm{R}$, hal ini disebakan karena dengan sistem 3R, direncanakan partisipasi masyarakat juga meningkat dengan menerapkan pola komunal langsung, dimana masyarakat langsung menuju ke wadah komunal mengantarkan timbulan sampah, sementara untuk kawasan yang memiliki bangunan TPS 3R masih menggunakan becak motor agar proses pengolahan terus berjalan, peningkatan becak motor pada sistem 3R disebabkan karena menigkatnya jumlah timbulan sampah yang diolah. Sementara untuk sarana pengangkutan sampah, alat angkut yang dibutuhkan pada sistem konvesional juga lebih banyak, hal ini disebabkan karena jumlah kontainer pada sistem ini juga lebih banyak.

4. Sampah yang masuk ke TPA

Perbandingan jumlah sampah yang masuk ke TPA dengan sistem konvesional dan sistem 3R dapat dilihat pada Tabel 17 dan Gambar 7.

Berdasarkan Tabel 17 dan Gambar 7 bahwa jumlah timbulan sampah yang masuk ke TPA dengan sistem $3 \mathrm{R}$ lebih sedikit dibandingkan jumlah sampah dengan menggunkan sistem $3 R$, hal ini disebakan adanya pengurangan sampah di TPS 3R yang direncanakan.
Tabel 17. Jumlah Timbulan Sampah yang masuk ke TPA Sistem Konesional Vs sistem 3R

\begin{tabular}{|lrr|}
\hline \multirow{2}{*}{ Tahap } & \multicolumn{2}{c|}{$\begin{array}{c}\text { Jumlah timbulan } \\
\text { sampah Kota Terlayani } \\
(\mathrm{m} 3 / \mathrm{h})\end{array}$} \\
\cline { 2 - 3 } & Konvesional & Sistem 3R \\
\hline Jangka Pendek & 383,38 & 361,11 \\
\hline Jangka Menengah & 489,73 & 438,32 \\
\hline Jangka Panjang & 672,08 & 537,27 \\
\hline
\end{tabular}

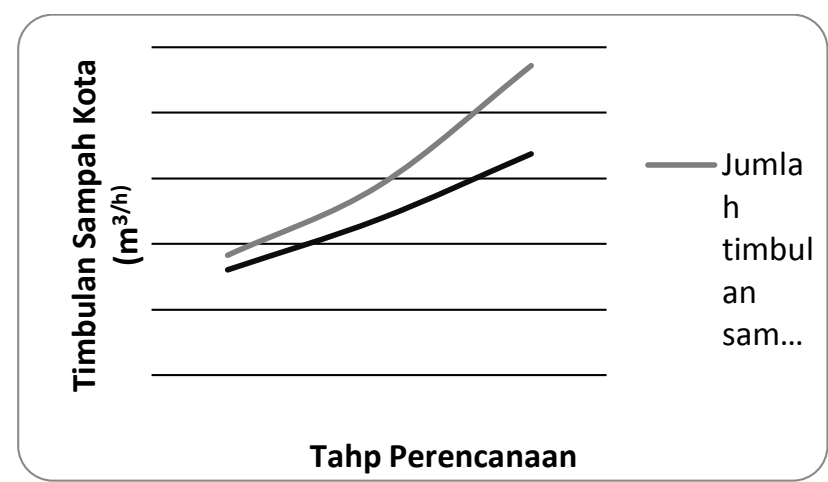

Gambar 7. Perbandingan jumlah Sampah

Kota Bukittinggi dengan Sistem Konvesional dan Sistem 3R

\section{PROGRAM DAN KEGIATAN}

Program dan kegiatan yang dilaksanakan dalam jangka pendek dari Tahun 2016-2020 terdiri teknis dan non teknis. Program dan kegiatan pengelolaan persampahan secara garis besar mencakup pengurangan sampah dari sumbernya dan meningkatkan layanan persampahan skala kawasan.

Kegiatan teknis dalam pengelolaan persampahan antara lain: 
1. Penambahan sarana pewadahan, pengumpulan dan pengangkutan sampah;

2. Perletakan wadah, penentuan jadwal dan rute pengangkutan Kota Bukittinggi;

3. Pembangunan TPS 3R Skala kawasan di Kelurahan Pulai Anak Aia dengan TPS 3R tipe I dan di Kelurahan Kayu Kubu dengan TPS 3R tipe II;

4. Optimalisasi TPS 3R di Kelurahan Aur Kuning (TPS 3R Tipe I);

5. Penutupan TPA sampah Panorama Baru. Kegiatan Non Teknis dalam pengelolaan persampahan antara lain:

1. Sosialisasi peraturan, perundangan dan sosialisasi tentang Perda pengelolaan sampah serta retribusi pelayanan persampahan/ kebersihan;

2. Sosialisasi Pengolahan sampah dengan metode 3R dengan masyarakat

3. Pelatihan teknis SDM untuk pengelolaan sampah di Kelurahan Aur kuning, Pulai Anak Aia dan Keluraha Kayu Kubu;

4. Pemantauan dan evaluasi pelaksanaan pelayanan persampahan Kota Bukittinggi;

5. Penguatan kelembagaan stekholder bidang persampahan (pola hubungan RT, RW , kelurahan, Kecamatan dengan DKP Kota Bukittinggi);

6. Sosialisasi prilaku tidak membuang sampah sembarangan;

7. Sosialisasi dan kampanye tata cara dan gerakan pemilahan sampah dari sumbernya;

8. Pelatihan tentang pengolahan sampah untuk Kelompok Swadaya Masyarakat (KSM) yang peduli lingkungan;

9. Sosialisasi tentang bank sampah.

\section{KESIMPULAN}

Berdasarkan analisis dan perencanaan sistem dan manajemen persampahan Kota Bukittinggi yang telah dilakukan maka berikut merupakan beberapa kesimpulan dari laporan tugas akhir ini adalah:

1. Kondisi persampahan Kota Bukittinggi belum mencapai standar yang seharusnya dengan tingkat dan daerah pelayanan hanya $55,7 \%$ dan $65,3 \%$;

2. Perencanaan tingkat pelayanan mencapai $100 \%$ (Zona I dan II) pada akhir periode perencanaan dengan persentase target $3 \mathrm{R}$ yaitu $20 \%$ dari sampah terlayani, untuk mempermudah monitoring maka dilakukan pembagian zona daerah pelayanan;

3. Perencanaan aspek teknis meliputi:

a. Pola pewadahan yang digunakan yaitu terpilah dan tidak terpilah. Pewadahan komunal direncanakan berupa kontainer dengan kapasitas $8 \mathrm{~m}^{3}$;

b. Pola pengumpulan direncanakan adalah pola individual tidak langsung, komunal langsung dan pola penyapuan jalan, dengan alat kumpul berupa becak motor dengan kapasitas $1,5 \mathrm{~m}^{3}$;

c. Pola pengangkutan yang direncanakan hingga akhir perencanaan berupa Hauled Container System (HCS) menggunakan amroll truck;

d. Bangunan pengolahan 3R berupa TPS 3R dengan sistem bank sampah yang terdiri atas tiga tipe yaitu Tipe I dengan luas $209 \mathrm{~m}^{2}$, Tipe II dengan luas 402,5 $\mathrm{m}^{2}$ dan Tipe III dengan luas $494 \mathrm{~m}^{2}$. Komposter yang digunakan berupa rotary kiln dan takakura susun;

e. Tempat pemprosesan akhir (TPA) sampah yang direncanakan yaitu TPA Regional Payakumbuh hingga TPA penuh pada pertengahan jangka panjang dan diperlukan pengakajian untuk lahan TPA yang baru.

4. Aspek non teknis, meliputi:

a. Menambah sub bidang pengolahan sampah di DKP Kota Bukittinggi, dan bekerjasama dengan Kabupaten lain untuk menekan jumlah timbulan dari Kabupaten tersebut;

b. Menetapkan pembiayaan dari retribusi masyarakat dan $\mathrm{ABPD}$;

c. Mempertegas peraturan-peraturan yang sudah ada;

d. Mengaktifkan peran serta masyarakat dalam pengelolaan sampah melalui berbagai sosialisasi dan pelatihan.

5. Berdasarakan analisis perbandingan pengelolaan sampah konvesional dan sistem 3R, bahwa pengelolaan sampah dengan sistem 3R dapat mengurangi julah sarana prasarana sampah yang digunakan.

\section{DAFTAR PUSTAKA}

Badan Pusat Statistik (BPS) Provinsi Sumatera Barat. 2015. Kota Bukittinggi Dalam Angka. Padang: BPS 
Damanhuri, Erni dan Tri Padmi. 2010. Diktat Kuliah Pengelolaan Sampah, Institut Teknologi Bandung:Bandung

Departemen Pekerjaan Umum Direktorat Jenderal Cipta Karya, Petunjuk Teknis Nomor CT/S/Re-TC/001/98 tentang Tata Cara Pengolahan Sampah 3M.

Departemen Pekerjaan Umum, 2008. Perencanaan Teknis Pengelolaan Sampah Terpadu 3R, Departemen Pekerjaan Umun Kota Semarang.

Departemen Pekerjaan Umum Direktorat Jenderal Cipta Karya. 2014 Tata Cara Penyelenggaraan Umum Tempat Pengolahan Sampah (TPS) 3R Berbasis Masyarakat di Kawasan Pemukiman.

Januar, Muhammad Anis. 2000. Peningakatan Teknis Operasional Pengelolaan Sampah Di Kota Malang. Universitas Diponegoro:

Pengelolaan Persampahan Kota Bukittinggi. 2014. Kota Bukittinggi: Dinas Kebersihan dan Pertamanan Kota Bukittinggi

Peraturan Menteri Pekerjaan Umum Nomor 3/PRT/M/2013. Penyelenggaraan Prasarana dan Sarana Persampahan dalam Penanganan Sampah Rumah Tangga dan Sampah Sejenis Sampah Rumah Tangga

Peraturan Menteri Pekerjaan Umum Nomor: 21/PRT/M/2006 tentang Kebijakan dan Stratehi Nasional Pengembangan Sistem Pengelolaan Persampahan.

Peraturan Daerah Kota Bukittinggi Nomor 6 Tahun 2011 tentang Rencana Tata Ruang Wilayah (RTRW) Kota Bukittinggi Tahun 2010 - 2030

Peraturan Menteri Dalam Negeri No 22 Tahun 2009 tentang Tata Cara Kerjasama Daerah.

Rahardyan B. dan Widagdo A.S., 2005. Peningkatan Pengelolaan Persampahan Perkotaan Melalui Pengembangan Daur Ulang. Materi Lokakarya 2 Pengelolaan Persampaham di Propinsi DKI Jakarta.

Syafrudin dan Priyambada I.B., 2001. Pengelolaan Limbah Padat. Diktat Kuliah Program Studi Teknik Lingkungan, Fakultas Teknik Undip: Semarang.

Standar Nasional Indonesia Nomor SNI-033241-1994 tentang Tata CaraPemilihan
Lokasi Tempat Pembuangan Akhir Sampah, Badan Standar Nasional(BSN)

Standar Nasional Indonesia Nomor SNI-033242-1994 tentang Tata Cara Pengelolaan Sampah di Permukiman, Badan Standar Nasional (BSN).

Standar Nasional Indonesia Nomor SNI-192454-2002 tentang Tata Cara Teknik Operasional Pengelolaan Sampah Perkotaan, Badan Standar Nasional (BSN)

Standar Nasional Indonesia Nomor SNI-193983-1995 tentang Spesifikasi Timbulan Sampah Untuk Kota Kecil dan Sedang di Indonesia, Badan Standar Nasional (BSN).

Standar Nasional Indonesia Nomor SNI-193964-1995 tentang Metode Pengambilan dan Pengukuran Contoh Timbulan Komposisi Sampah di Perkotaan, Badan Standar Nasional (BSN).

Tchobanoglous, G., Teisen H., Eliasen, R, 1977, Integrated Solid Waste Manajemen, Mc.Graw Hill : Kogakusha, Ltd

Undang-Undang Republik Indonesia Nomor 18 Tahun 2008, Tentang Pengelolaan Sampah

Unit Pelaksana Teknis Daerah (UPTD) Sampah Provinsi Sumatera Barat. 2014. TPA Sampah Regional Payakumbuh. Padang: UPTD Sampah

Yones, Indra. 2007. Kajian Pengelolaan Sampah Di Kota Ranai Ibu Kota Kabupaten Natuna Propinsi Kepulauan Riau. Universitas Diponegoro:Semarang 